\title{
Szemfenéki angioid csíkok szisztémás betegségekben
}

\author{
Kriskó Dorottya dr. ${ }^{1}$ - Popper-Sachetti Andrea dr. ${ }^{2}$. Sallai Ágnes dr. ${ }^{2}$ \\ Sándor Gábor dr. ${ }^{1}$. Nagy Zoltán Zsolt dr. ${ }^{1}$. Szepessy Zsuzsanna dr. ${ }^{1}$
}

\author{
'Semmelweis Egyetem, Általános Orvostudományi Kar, Szemészeti Klinika, Budapest \\ ${ }^{2}$ Pándy Kálmán Központi Kórház, Gyula
}

\begin{abstract}
Angioid csíkokon a szemfenék speciális morfológiai elváltozását értjük, amely klinikailag a leggyakrabban szabálytalan, eltérő vastagságú, vöröses, barnás csíkok formájában jelenik meg a látóidegfő körül, illetve a hátsó póluson. Szövettani vizsgálat alapján a jelenség okai az elvékonyodott Bruch-membrán rétegében látható repedések, folytonossághiányok, amelyeket az elasztikus rostok degenerációja okoz. Célunk három eset ismertetésén keresztül bemutatni ezen ritka entitás szemészeti szövődményét, illetve felhívni a figyelmet a háttérben esetlegesen előforduló szisztémás betegségekre. Első és harmadik esetünkben pseudoxanthoma elasticum (Grönblad-Strandberg-szindróma) állt a háttérben, míg második esetünkben hematológiai megbetegedés igazolódott. Az elsố és második esetben a szemészeti szövődmény chorioidealis érújdonképződés volt, amelyet intravitrealis anti-VEGF-injekcióval kezeltünk. Harmadik esetünkben trauma következtében egy másik jellegzetes szemészeti szövődmény, chorioidearuptura alakult ki. Az angioid csíkok a szemfenéken szisztémás betegségek részjelenségei lehetnek, amelyek kimutatása, differenciáldiagnosztikája és kezelése interdiszciplináris összefogást igényel a társszakmák orvosai között.
\end{abstract}

Orv Hetil. 2019; 160(25): 994-1000.

Kulcsszavak: angioid csík, pseudoxanthoma elasticum, Bruch-membrán, trauma

\section{Angioid streaks in systemic disease}

Angioid streaks are defined as the special morphological alteration of the fundus; the most common clinical manifestations are irregular, reddish brownish stripes around the optic nerve head or on the posterior pole. On the basis of histological examination, the cause of this phenomenon is the breaks and continuity deficiencies in the thin layer of Bruch membrane caused by the degeneration of elastic fibers. The aim of this study is to present the ocular complication of this rare entity through the description of three cases, and to draw attention to systemic diseases in the background. In our first and third cases, pseudoxanthoma elasticum (Grönblad-Strandberg syndrome) was in the background, while in our second case, hematological disease was confirmed. In our first and second cases, the ocular complication was the choroidal neovascularization, which we treated with intravitreal anti-VEGF injection. In our third case, the choroidal rupture was the ocular complication, caused by trauma. Angioid streaks on the fundus may be sub-phenomena of systemic diseases, the detection, differential diagnosis and treatment require interdisciplinary collaboration between associate physicians.

Keywords: angioid streaks, pseudoxanthoma elasticum, Bruch membrane, trauma

Kriskó D, Popper-Sachetti A, Sallai Á, Sándor G, Nagy ZZs, Szepessy Zs. [Angioid streaks in systemic disease]. Orv Hetil. 2019; 160(25): 994-1000.

(Beérkezett: 2019. január 28.; elfogadva: 2019. február 7.)

\section{Rövidítések}

ABCC6 = (ATP-binding cassette sub-family C member 6) ATP-kötő kazettafehérje C-alcsaládjának 6. tagja; ATP = (adenosine triphosphate) adenozin-trifoszfát; $\mathrm{CNV}=$ chorioidealis neovascularisatio; $\mathrm{kml}=$ kézmozgáslátás; $\mathrm{MRP6}=$ (multidrug resistance-associated protein 6) multidrogrezisztenciához társuló fehérje-6; OCT $=$ (optical coherence tomography $)$ optikaikoherencia-tomográfia; TIA $=$ (transient ischemic attack) átmeneti agyi keringészavar; VEGF = (vascular endothelial growth factor) vascularis endothelialis növekedési faktor 
A Bruch-membrán a retinalis pigmentepithelium és a choriocapillaris réteg között található sejtmentes struktúra. Elasztin- és kollagéntartalmú extracelluláris mátrixból áll, melyet a choriocapillaris és a retinalis pigmentepithelium termel. Szerkezetének kialakulásában fontos szerep jut az ún. mátrixmetalloproteázoknak, amelyek felelősek az extracelluláris mátrix folyamatos átépüléséért is [1]. Ezen anyagok génexpressziója határozza meg a Bruch-membrán pontos szerkezetét. A membrán felépítése a retina különböző területein eltérő vastagságú és összetételű. Legfontosabb funkciói közé tartozik a retina és a chorioidea közötti oxigén, tápanyagok és a metabolizmus során keletkező anyagcseretermékek transzportfolyamatainak szabályozása $[1,2]$. Fontos szerepet játszik még a retinalis pigmentepithelium sejtjeinek adhéziójában és differenciálódásában, illetve támasztó funkciója elengedhetetlen a külső vér-retina gát megfelelő múködéséhez [2].

A Bruch-membrán szerkezetének károsodása jelentős funkcionális eltérésekhez vezethet. Ennek egyik formája az életkor előrehaladása miatt kialakult változás, melyet önmagában nem tekintünk patológiás folyamatnak; a másik az angioid csíkok létrejötte.

Angioid csíkok (streaks) kifejezésen a szemfenék speciális morfológiai elváltozását értjük. Leggyakoribb klinikai megjelenése a szemfenékvizsgálat során észlelt szabálytalan, eltérő vastagságú, vöröses, barnás csíkok a látóidegfó körül radier irányban, illetve a hátsó póluson [2]. A csíkok helyzete és lefutása a nagyerekre emlékeztet, innen a betegség neve is (érhez hasonló csíkok). Szövettani vizsgálat alapján a jelenség okai az elvékonyodott Bruch-membrán rétegében látható repedések, folytonossághiányok, amelyeket a kollagén- és elasztikus rostok degenerációja okoz $[1,3]$.

$\mathrm{Az}$ angioid csíkok általában nem okoznak szemészeti tüneteket, csak akkor, ha az éleslátás helyén a Bruchmembrán repedésein a sérült, degenerálódott pigmentepitheliumon keresztül érburjánzás indul a choriocapillaris rétegből a retina felé. Szemészek számára azonban a tünetmentes angioid csíkok megléte a szemfenéken alapos kivizsgálást és szoros nyomon követést igényel.

Jelen közleményünk célja három eset bemutatása, amelyekben a szemészeti panaszok hátterében angioid csíkok okozta érújdonképződés áll, de a betegek alapos kivizsgálása során szisztémás, belgyógyászati és bőrgyógyászati betegségek igazolódtak.

\section{Első eset}

Egy 47 éves férfi beteg a jobb szemének látásromlása, foltlátása miatt került intézetünkbe. Anamnézisében a belgyógyászati betegségek közül kezelt hypertonia szerepelt. Szemészeti anamnéziséből kiemelendő, hogy egy évvel intézetünkbe kerülése előtt bal szemén jelentősen megromlott a látása. Szemészeti vizsgálatakor a legjobb korrigált látóélessége (decimálisan) jobb szemén 1,0, bal szemén pedig kml (kézmozgáslátás) volt. Amsler-rács se-

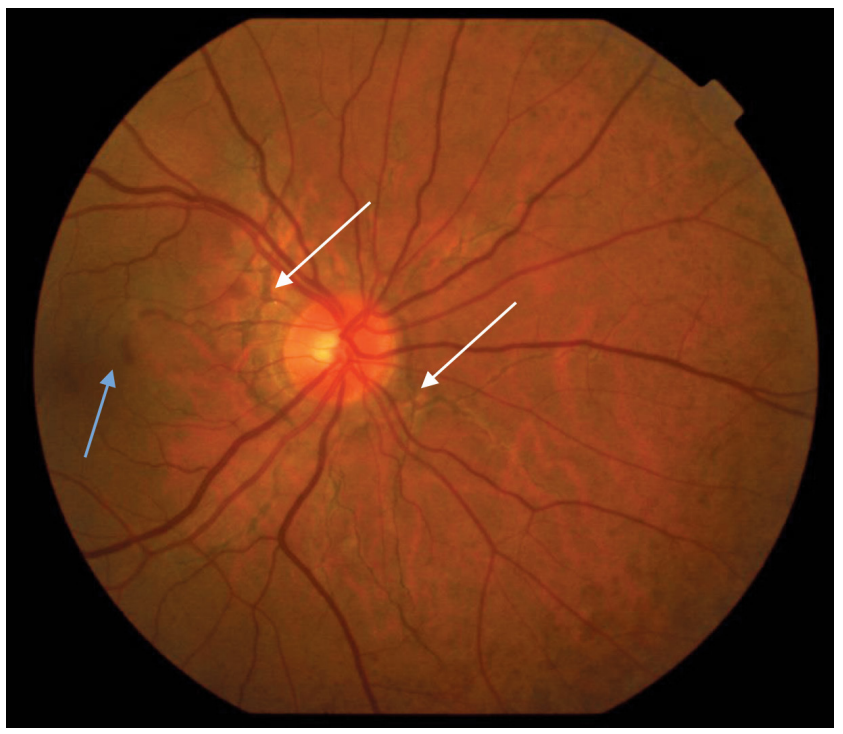

1. ábra

Első esetünk jobb oldali szemfenéki képe - angioid csíkok. Papilla körüli radier irányban futó vöröses, barnás csíkok (angioid csíkok) láthatók (fehér nyíl), a maculában kis subretinalis vérzéssel (kék nyíl)

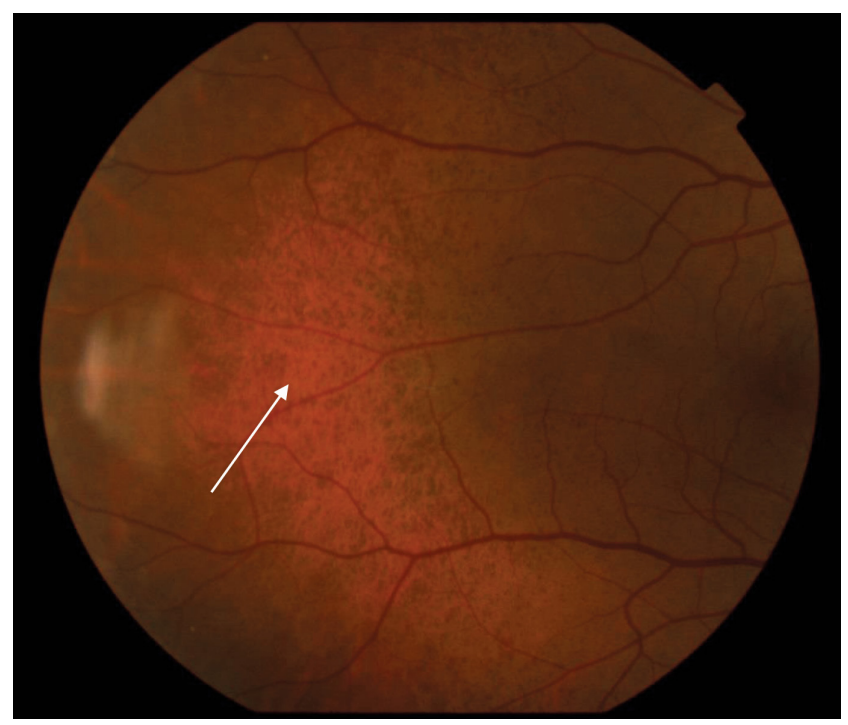

2. ábra A pseudoxanthoma elasticum jellegzetes perifériás retinaeltérése. A retina perifériáján narancssárga színú szemcséződést mutató terület (peau d'orange) (nyíl) (első eset)

gítségével a jobb szemén centrális scotoma volt kimutatható. Réslámpás vizsgálat során mindkét oldalon békés elülső szegmentumot láttunk. Biomikroszkópos szemfenékvizsgálat során mindkét oldalon a papilla körül vöröses, barnás csíkokat (angioid csíkok), jobb szemén a maculában vérzést és serosus leválást láttunk (1. ábra), a periférián pedig narancssárga színú szemcséződést (peau d'orange) találtunk (2. ábra). A bal oldalon az angioid csíkokon kívül, a maculában hegképződés volt megfigyelhető, ez okozta a bal szem korábbi, jelentős látásromlását (3. ábra). Macula-OCT-vizsgálata megerősítette a jobb maculában látható subretinalis folyadékot és a fotoreceptorréteg feltöredezettségét pigmenthámlevá- 


ESETISMERTETÉS



3. ábra

Első esetünk bal oldali szemfenéki képe - heg a maculában.
A bal oldali szemfenéken az angioid csíkokon kívül, a maculában
hegképződés látható (nyíl)

lással, míg a bal oldalon a heges chorioidealis neovascularisatiót (CNV) (4/A ábra).

A beteg a jobb szemén 3 alkalommal intravitrealis anti-VEGF (aflibercept)-kezelésben részesült, amelynek adása után a subretinalis folyadék felszivódott, a beteg

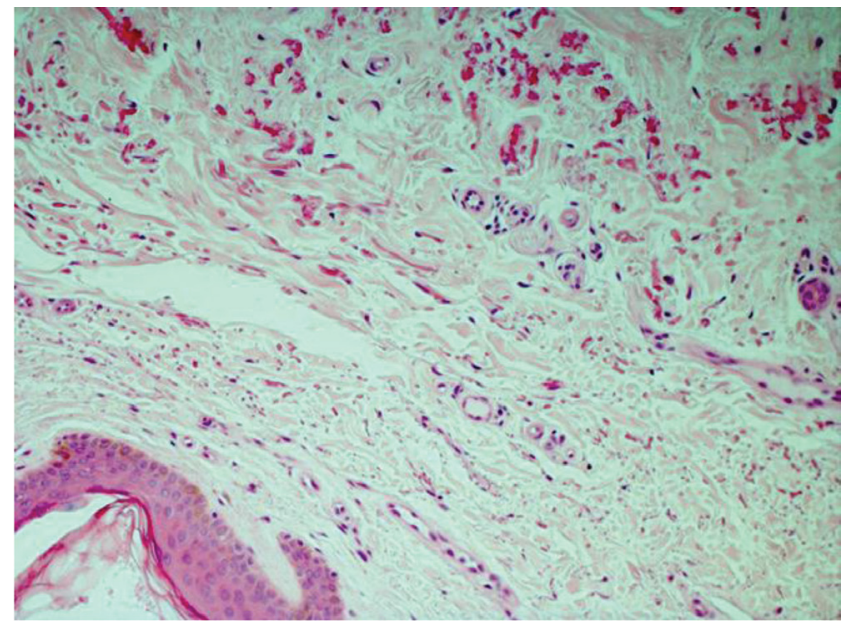

5. ábra

A pseudoxanthoma elasticum szövettani metszete a bőrből A megtartott felszíni hám alatt, ép papillaris dermis és a dermis közepétől kezdődően a kimetszés aljáig terjedve a dermalis kollagénrostok között granuláris jellegü, sötét eozinofil csoportok látszanak, amelyek megfelelnek degeneratív felrostozódott és feltekeredett elasztikus rostoknak (HE 200×) (első eset)

centrális foltlátása megszúnt, látóélessége 1,0 maradt (4/B ábra).

$\mathrm{Az}$ angioid csíkok miatt azonban általános kivizsgálást indítottunk betegünknél, amelynek során rutinlaborleletében eltérés nem volt. Belgyógyászati kivizsgálása a

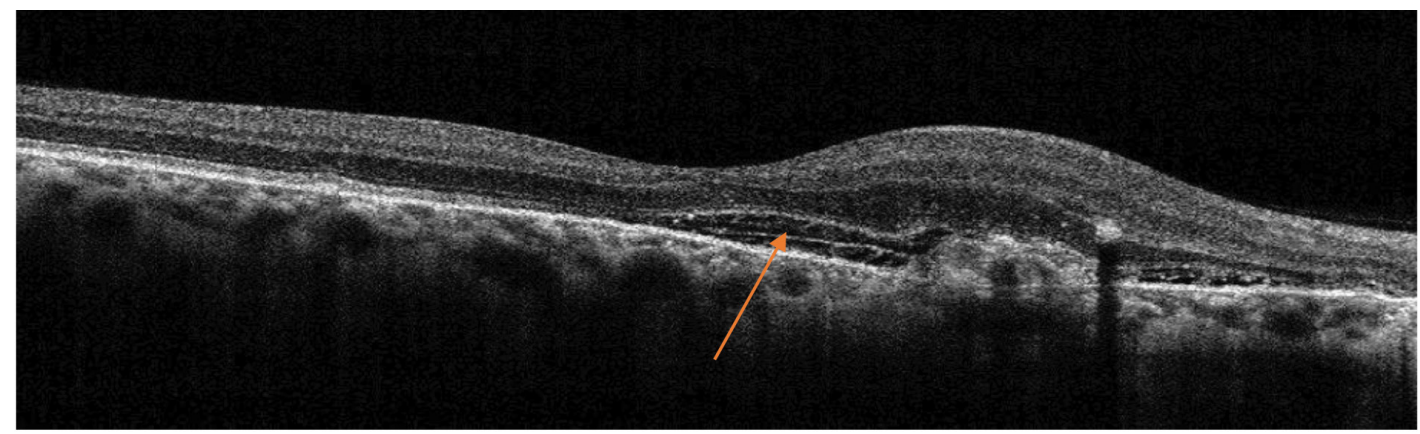

4/A ábra $\quad$ Első esetünk jobb szemének macula-OCT-felvétele - chorioidealis neovascularisatio (CNV). Macula-OCT-felvételen subretinalis folyadék (nyíl), a fotoreceptorréteg feltöredezettsége, pigmenthámleválás és a pigmenthám-choriocapillaris komplex megvastagodása látható

OCT $=$ optikaikoherencia-tomográfia

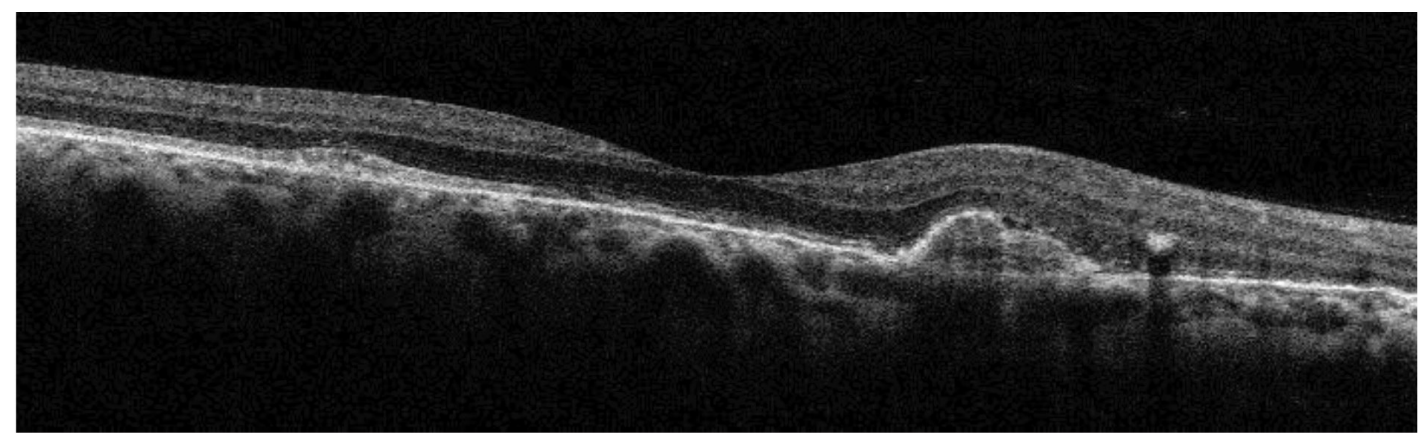

4/B ábra | Első esetünk jobb szemének macula-OCT-felvétele anti-VEGF-kezelés után. Intravitrealis anti-VEGF-kezelés után a subretinalis folyadék felszívódott, a betegség aktivitása megszúnt

OCT $=$ optikaikoherencia-tomográfia VEGF $=$ vascularis endothelialis növekedési faktor 


\section{ESETISMERTETÉS}

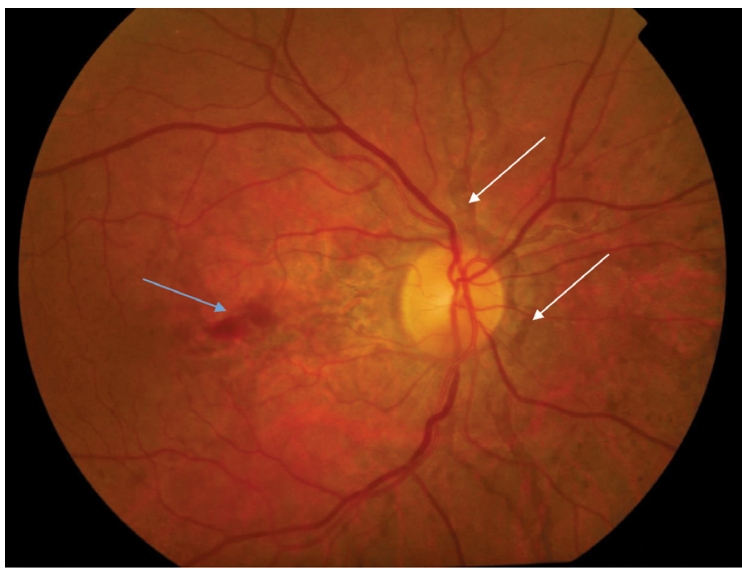

6. ábra

Második esetünk jobb oldali szemfenéki képe - angioid csíkok. A papilla körül angioid csíkok (fehér nyíl), a maculában subretinalis vérzés (kék nyíl) látható

hypertonián kívül más eltérést nem talált. Érsebészeti és kardiológiai kivizsgálása is negatív eredménnyel zárult. Bőrgyógyászati vizsgálata a nyak két oldalán szimmetrikusan jellegzetes, csirkebőrre emlékeztető sárgás multi- plex papulákat írt le, ami felvetette a pseudoxanthoma elasticum (Grönblad-Strandberg-szindróma) valószínúségét. Ezt a diagnózist a bőrből vett szövettani vizsgálat megerősítette (5. ábra).

\section{Második eset}

Egy 65 éves nőbeteg a jobb szemének látásromlása, foltlátása miatt került intézetünkbe. Anamnézisében szemészeti megbetegedés nem, a belgyógyászati betegségek közül kezelt hypertonia, valamint reumatológiai/ortopédiai kezelések szerepeltek veleszületett csípőficam miatt. Szemészeti vizsgálatakor a legjobb korrigált látóélessége a jobb szemén 0,25 , a bal szemén 1,0 volt. Amsler-rács segítségével a jobb szemén centrális scotoma volt kimutatható. Réslámpás vizsgálat során mindkét oldalon békés elülső szegmentumot láttunk. Biomikroszkópos szemfenékvizsgálat során mindkét oldalon a papilla körül vöröses, barnás csíkokat (angioid csíkok), a jobb oldalon a maculában vérzést (6. ábra) és serosus leválást láttunk (7/A ábra), míg a bal oldalon az angioid csíkokon kívül a maculában pigmentzavar volt megfigyelhető.

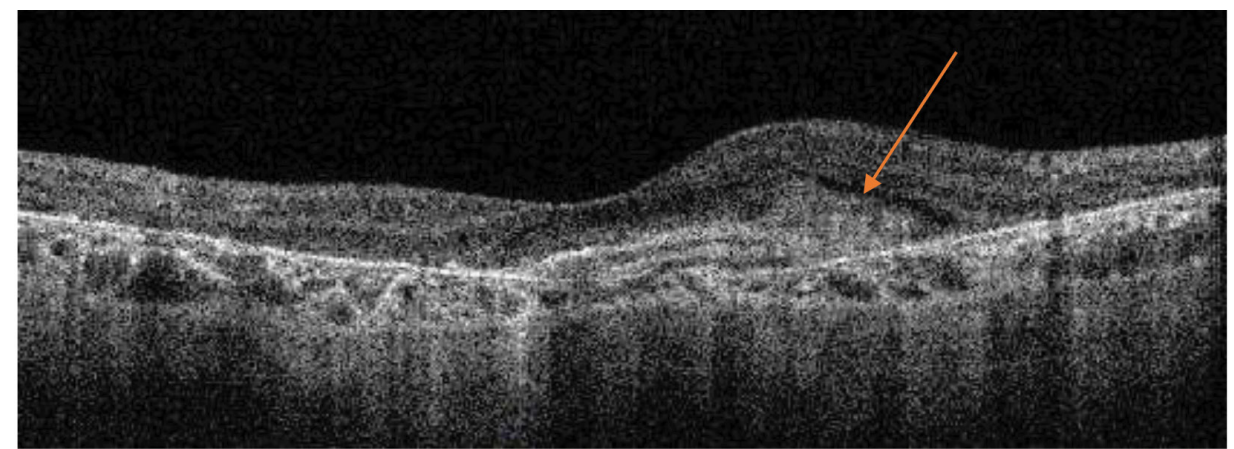

Második esetünk jobb szemének macula-OCT-felvétele - chorioidealis neovascularisatio (CNV). Macula-OCT-felvételen subretinalis folyadék (nyíl) és a pigmenthám-choriocapillaris komplex megvastagodása látható

OCT $=$ optikaikoherencia-tomográfia

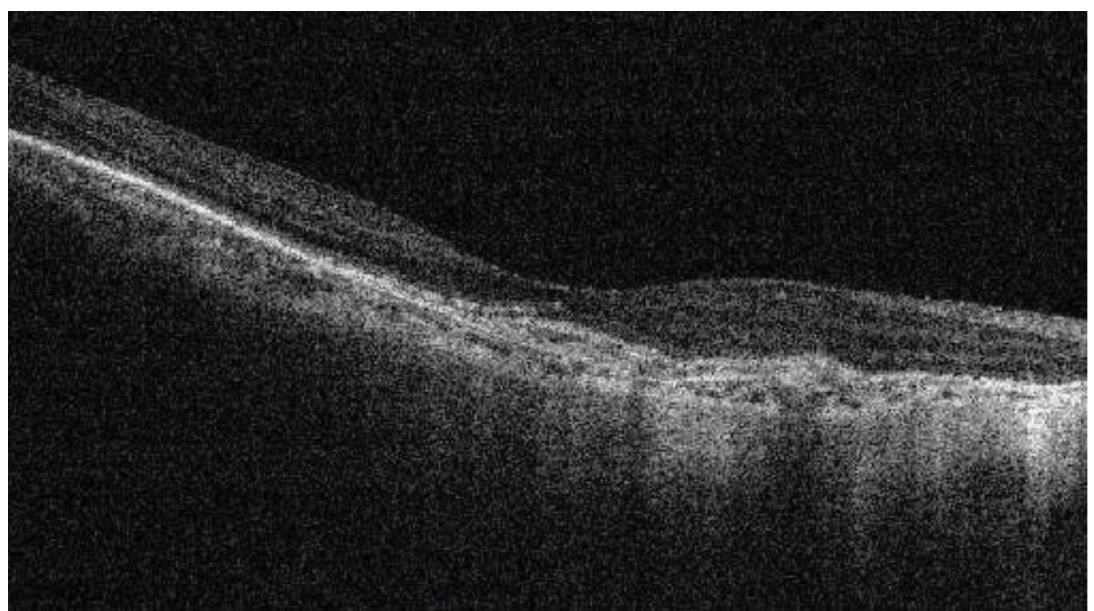

7/B ábra $\quad$ Második esetünk jobb szemének macula-OCT-felvétele anti-VEGF-kezelés után. Intravitrealis anti-VEGF-kezelés után a subretinalis folyadék felszívódott, a betegség aktivitása megszúnt

OCT $=$ optikaikoherencia-tomográfia; VEGF $=$ vascularis endothelialis növekedési faktor 
A beteg a jobb szemén 5 alkalommal intravitrealis anti-VEGF (aflibercept)-kezelésben részesült, amelynek adása után a subretinalis folyadék felszívódott; a beteg látóélessége 0,5 lett ( $7 / B$ ábra).

$\mathrm{Az}$ angioid csíkok miatt indított általános kivizsgálás során hematológiai betegséget, idiopathiás thrombocytopeniát diagnosztizáltak (thrombocytaszám: $80 \times$ $\left.10^{9} / 1\right)$ A beteg általános szteroidkezelésben részesült.

\section{Harmadik eset}

Egy 40 éves férfi beteg a bal szemének látásromlása miatt került intézetünkbe. Anamnézisében belgyógyászati és szemészeti betegség nem szerepelt, azonban kiemelendő, hogy néhány héttel korábban megütötték, és trauma érte a bal szemét. Szemészeti vizsgálatakor a legjobb korrigált látóélessége a jobb szemén 1,0, a bal szemén 0,2 volt. Réslámpás vizsgálat során mindkét oldalon békés elülső szegmentumot találtunk. Biomikroszkópos szemfenékvizsgálat során mindkét oldalon a papilla körül vöröses, barnás csíkokat (angioid csíkok), a bal szemén a maculában chorioidearupturának megfelelően vérzést láttunk (8. ábra), a jobb oldalon a macula ép volt. Fluoreszcens angiográfiával a jobb szemnél a vérzéseknek megfelelően blokkolást, míg a késő stádiumban festékszivárgást láttunk a rupturának megfelelően (9. ábra). A beteg a felajánlott, a látásjavulást biztosan nem ígérő kezelést elutasította.

$\mathrm{Az}$ angioid csíkok miatt végzett általános kivizsgálás során első esetünkhöz hasonlóan pseudoxanthoma elasticum (Grönblad-Strandberg-szindróma) igazolódott. Érsebészeti, kardiológiai vizsgálata során eltérést nem találtak.

\section{Megbeszélés}

$\mathrm{Az}$ angioid csíkok hátterében több szisztémás megbetegedés szerepelhet, amelyeket az 1. táblázatban foglaltunk össze.

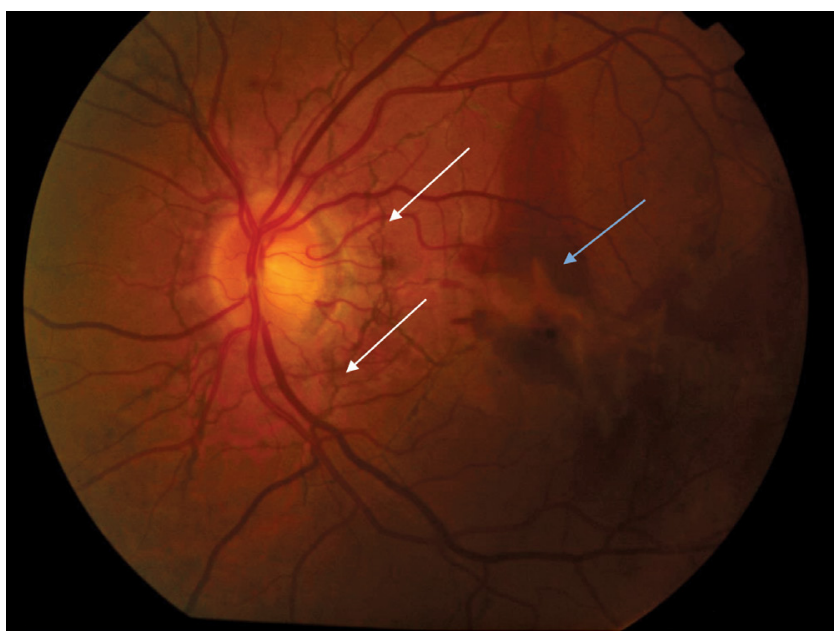

Harmadik esetünk bal oldali szemfenéki képe - angioid csíkok és chorioidearuptura. A papilla körül angioid csíkok (fehér nyíl), a maculában chorioidearuptura (kék nyíl) okozta vérzés látható
Két esetünkben (szövettanilag is igazolt) angioid csíkok hátterében szisztémás bőrbetegség, a pseudoxanthoma elasticum állt.

A pseudoxanthoma elasticum autoszomális recesszív öröklődésmenetet mutató genetikai anyagcsere-betegség. A hibás múködésû génszakasz is ismert, a pontos patomechanizmus azonban nem teljesen tisztázott. Jelen ismereteink szerint a genetikai defektusért az ABCC6gén kódolta MRP6-protein tehető felelőssé. Az ABCC6gén mutációját örökletes genetikai faktorok és környezeti tényezők is befolyásolhatják [4]. Az MRP6-protein az elasztikus anyagban gazdag szövetekben: a bőrben, az erekben és a szemben manifesztálódik. A betegséget az elasztikus rostok feltöredezése és progresszív kalcifikációja jellemzi, ami a szem Bruch-membránjában is megfigyelhető. Az érintett területeken kalciumvegyületek (kalcium-hidrogénfoszfát, kalcium-hidroxiapatit) és az esetek egy részében vasvegyületek halmozódnak fel. Elsősorban a nők érintettek, a prevalencia 1/25 000100000 [5]. Az első klinikai jelek többnyire kamaszkor-
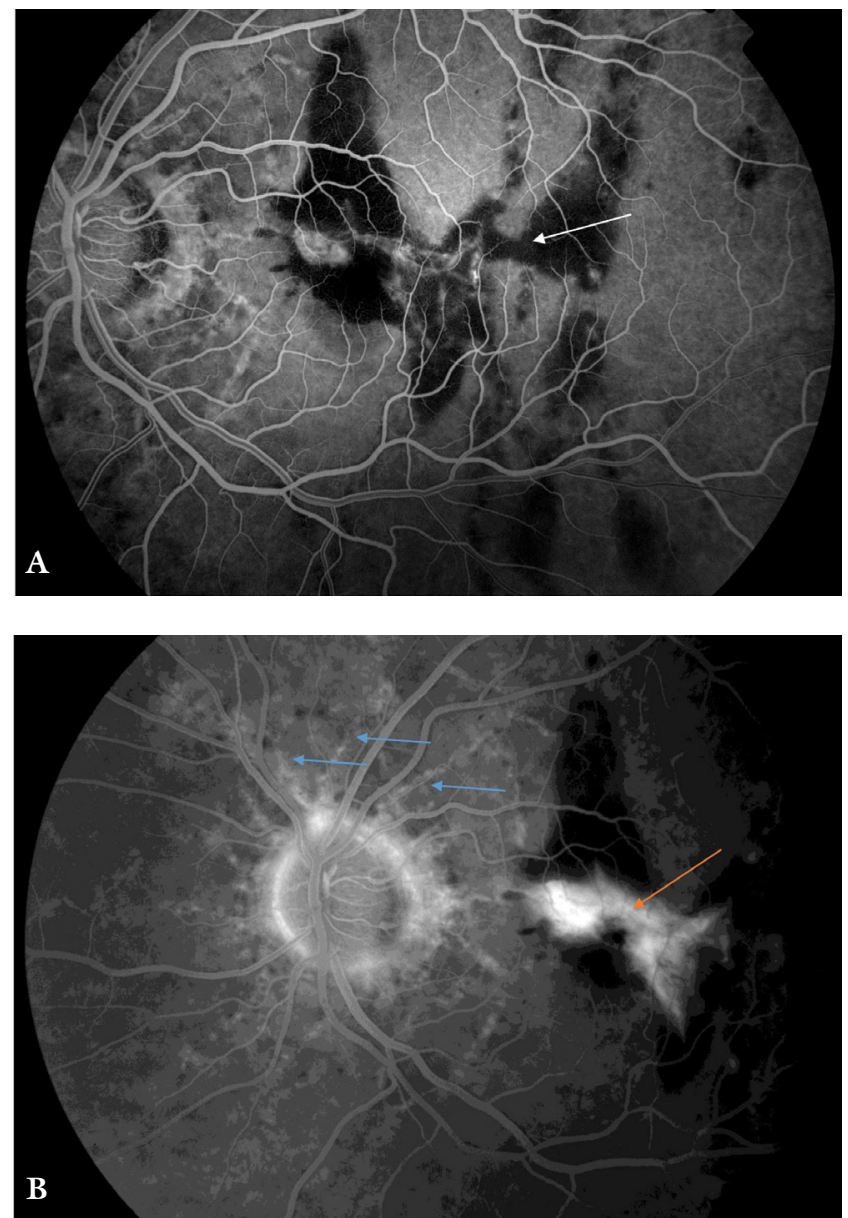

9. ábra

Harmadik esetünk bal oldali fluoreszcens angiográfiás felvétele

A: Fluoreszcens angiográfiás korai felvételen a vérzéseknek megfelelően blokkolás látható (fehér nyíl)

B: Fluoreszcens angiográfiás késői felvételen a chorioidearupturának megfelelően festékszivárgás látható (sárga nyíl). Az angioid csíkok a papilla körül jól diagnosztizálhatók (kék nyíl) 
1. táblázat

A leggyakoribb betegségek, amelyekhez angioid csíkok társulhatnak

\begin{tabular}{ll}
\hline Szisztémás betegségek & Hematológiai betegségek \\
\hline Pseudoxanthoma elasticum & Sarlósejtes anaemia \\
\hline Paget-kór & Thalassaemia \\
\hline Acromegalia & Spherocytosis \\
\hline Marfan-szindróma & $\begin{array}{l}\text { Öröklött haemolyticus anaemia } \\
\text { (például idiopathiás thrombocytopenia) }\end{array}$ \\
\hline Ehlers-Danlos-szindróma & \\
\hline Lipoproteinaemia & \\
\hline Sturge-Weber-szindróma & \\
\hline Neurofibromatosis & \\
\hline
\end{tabular}

ban mutatkoznak, apró sárgás papulák jelennek meg a nyakszirten és a hajlatokban (a hónaljak, a köldök területén, inguinalisan, a térdhajlatban); a száj-, a hüvely- és a végbélnyálkahártya is érintett lehet. Az apró papulák a betegség előrehaladtával nagyobb, összefüggő plakkokká egyesülnek, utcakőrajzolatra hasonlító képet mutatva. $\mathrm{Az}$ érintett bőrterület laza szerkezetưvé és ráncossá válik („csirkebőrtünet”) [6]. A bőrből történő szövettani mintavétel során az ép felszíni hám alatt degeneratív, felrostozódott és feltekeredett elasztikus rostok válnak láthatóvá [3].

A szemészeti érintettség a nagy elasztintartalmú Bruch-membrán kalcifikációja miatt alakul ki, a szemfenéken megjelennek az angioid csíkok. Tünetek akkor jelentkeznek, ha a macula területén neovascularisatio kezdődik (CNV), vérzés, ödéma jön létre (első esetünk), illetve ha trauma hatására a Bruch-membrán teljes vastagságában megreped (harmadik esetünk). Első esetünkben a bal szem látóélességének megromlása egy korábban kialakult és nem kezelt chorioidealis neovascularisatióval magyarázható. Trauma kapcsán nemcsak a szemgolyót érő sérülésekre, hanem a fejsérülésekre is gondolni kell, mert bármilyen, fejet ért trauma is kiválthat ezen betegeknél chorioidearepedést.

A vascularis rendszer elváltozásai többnyire évekkel a bőr és a szemészeti tünetek után jelentkeznek, elsősorban a közepes és kis átmérőjü erek tunica media és intima része érintett, ami miatt claudicatio intermittens jelentkezhet. Néhány esetismertetésben TIA (átmeneti agyi keringészavar), stroke, aneurizmaképződés, a carotisok stenosisa is szerepel, így javasolt érsebészeti és kardiológiai kivizsgálást végezni. A Grönblad-Strandbergszindróma esetén sokszor van jelen a cerebrovascularis vérzés mellett gastrointestinalis vagy húgyúti vérzés is [6].

A diagnózis felállítása a bőr- és a szemtünetek, vagyis a major kritériumok fennállása esetén egyértelmú akkor is, amennyiben az ABCC6-gén mutációjának vizsgálata nem lehetséges molekuláris genetikai módszerrel. A kezelés elsősorban attól függ, hogy mely szervrendszer érintett. Amennyiben csupán bőrtünetek jelentkeznek, antioxidánsok fogyasztása javasolt; elsősorban tokoferol, illetve aszkorbinsav fogyasztását javasolják mérsékelt kalciumbevitel mellett [3]. Szemészeti érintettségkor, chorioidealis neovascularisatio esetén az elsőként választandó terápia az intravitrealis anti-VEGF-injekció adása, amelyre az irodalmi adatok alapján jól reagálnak a betegek [7]. Az érrendszeri érintettség tekintetében a legfontosabb a cardiovascularis rizikófaktorok lehetőség szerinti csökkentése; perifériás érbetegség esetén érsebészeti mütétre is sor kerülhet.

Kötőszöveti betegségek - például Marfan-szindróma, Ehlers-Danlos-szindróma - eseteiben is kialakulhatnak angioid csíkok, így fontos a szemfenék vizsgálata ezekben a betegcsoportokban [6].

A hematológiai megbetegedések a másik fó csoport, ahol angioid csíkok kialakulására lehet számítani, ezért minden ilyen betegnél javasolt a hematológiai kivizsgálás. Haemoglobinopathiáknál (például $\beta$-thalassaemia, sarlósejtes anaemia) különösen kell gondolni angioid csíkok jelenlétére a szemfenéken $[8,11]$.

Autoimmun haemolyticus anaemia során ellenanyagok termelődnek a vér alakos elemei, különösképpen a vörösvértestek sejtmembránjának bizonyos alkotórészei ellen, ami hemolízishez vezet. A betegség társulhat szisztémás autoimmun kórképekhez, daganatokhoz, de előfordulhat önmagában is [12]. Második esetünkben is egy autoimmun folyamatot, a vérlemezkéket érintő, idiopathiás thrombocytopeniát diagnosztizáltak a kivizsgálás során. Az idiopathiás thrombocytopeniás purpura gyermekeknél jól ismert, felnőttkorban ritkábban előforduló kórkép, de az irodalmi adatok alapján időskorban 22\%-ban társul szemfenéki angioid csíkok jelenlétével [7].

\section{Következtetés}

Elmondható, hogy a tünetmentes angioid csíkok szemészeti kezelést nem igényelnek, de folyamatosan nyomon kell követni a betegeket, illetve az általános kivizsgálásukra nagy hangsúlyt kell fektetni, mert az egész szervezetet érintő rendszerbetegségek állhatnak a háttérben. Szemészek számára azért fontos a nyomon követésük, mert a chorioidearuptura veszélye (különösen trauma esetén), illetve a chorioidealis érújdonképződés kialakulásának valószínűsége is nagyobb, ami speciális, intravitrealis anti-VEGF-terápiát indikál.

Cikkünkkel szerettük volna felhívni a figyelmet erre a ritka szemfenéki eltérésre, amelynek hátterében több szervet is érintő szisztémás betegségek állhatnak; ezek differenciáldiagnosztikája és kezelése interdiszciplináris összefogást igényel a társszakmák orvosai között.

Anyagi támogatás: A közlemény megírása, illetve a kapcsolódó kutatómunka anyagi támogatásban nem részesült.

Szerzői munkamegosztás: Sz. Zs., P.-S. A., N. Z. Zs.: A vizsgálat tervezése. K. D., Sz. Zs., P.-S. A., S. Á., S. G.: 
A vizsgálatok elvégzése. K. D., Sz. Zs.: A közlemény megírása. N. Z. Zs.: A közlemény kritikai revíziója. A cikk végleges változatát valamennyi szerző elolvasta és jóváhagyta.

Érdekeltségek: A szerzőknek nincsenek érdekeltségeik.

\section{Köszönetnyilvánítás}

Dr. Poczik Sándor patológusnak (Pándy Kálmán Központi Kórház, Gyula) köszönjük, hogy a szövettani felvételeket rendelkezésünkre bocsátotta.

\section{Irodalom}

[1] Booij JC, Baas DC, Beisekeeva J, et al. The dynamic nature of Bruch's membrane. Prog Retin Eye Res. 2010; 29: 1-18.

[2] Georgalas I, Papaconstantinou D, Koutsandrea C, et al. Angioid streaks, clinical course, complications, and current therapeutic management. Ther Clin Risk Manag. 2009; 5: 81-89.

[3] Georgalas I, Tservakis I, Papaconstaninou D, et al. Pseudoxanthoma elasticum, ocular manifestations, complications and treatment. Clin Exp Optom. 2011; 94: 169-180.

[4] Germain DP. Pseudoxanthoma elasticum. Orphanet J Rare Dis. 2017; $12: 85$.

[5] Kranenburg G, Baas AF, de Jong PA, et al. The prevalence of pseudoxanthoma elasticum: revised estimations based on geno- typing in a high vascular risk cohort. Eur J Med Genet. 2019; 62: 90-92.

[6] Sebök B, Zombai E, Kiss A. Pseudoxanthoma elasticum. [Pseudoxanthoma elasticum.] Orv Hetil. 1986; 127: 77-80. [Hungarian]

[7] Gliem M, Finger RP, Fimmers R, et al. Treatment of choroidal neovascularization due to angioid streaks: a comprehensive review. Retina 2013; 33: 1300-1314.

[8] Liaska A, Petrou P, Georgakopoulos CD, et al. $\beta$-Thalassemia and ocular implications: a systematic review. BMC Ophthalmol. 2016; 16: 102

[9] Meier ER. Treatment options for sickle cell disease. Pediatr Clin North Am. 2018; 65: 427-443.

[10] Kurdi B, Mezei ZA, Kellner Á, et al. Pernicious anemia in a thalassemic patient - difficulties of the diagnosis. [Thalassaemiás betegen észlelt anaemia perniciosa - a diagnózis nehézségei.] Orv Hetil. 2018; 159: 1368-1371. [Hungarian]

[11] Szelényi J, Földi J, Horányi M, et al. Hemoglobinopathies in Hungary. [Hemoglobinopátiák Magyarországon.] Orv Hetil. 1987; 128: 1131-1136. [Hungarian]

[12] Udvardy M. Immune thrombocytopenic purpura (ITP). [Immunthrombocytopeniás purpura (ITP).] Orv Hetil. 2001; 142: 2723-2730. [Hungarian]

(Szepessy Zsuzsanna dr., Budapest, Üllői út 26., 1085 e-mail: szepzsu@yahoo.com)

\section{"Felicitas multos habet amicos." (Boldog embernek sok a barátja.)}

A cikk a Creative Commons Attribution 4.0 International License (https://creativecommons.org/licenses/by/4.0/) feltételei szerint publikált Open Access közlemény, melynek szellemében a cikk bármilyen médiumban szabadon felhasználható, megosztható és újraközölhetö, feltéve, hogy az eredeti szerző és a közlés helye, illetve a CC License linkje és az esetlegesen végrehajtott módosítások feltüntetésre kerülnek. (SID_1) 